\title{
POLYMINERALIC ECLOGITIC INCLUSIONS IN GUANIAMO DIAMONDS, VENEZUELA: EVIDENCE FOR VARIABLE DIAMOND GROWTH CONDITIONS
}

\author{
Nikolai V. Sobolev ${ }^{1}$, Alla M. Logvinova ${ }^{1}$, Emiliya S. Yefimova ${ }^{1}$, Dmitry A. Zedgenizov ${ }^{1}$ and \\ Dominic M. DeR. Channer \\ ${ }^{1}$ Institute of Mineralogy and Petrography, Russian Academy of Sciences, Siberian Branch, Novosibirsk, Russia; ${ }^{2}$ Guaniamo \\ Mining Company, Venezuela
}

\section{INTRODUCTION}

The Guaniamo diamondiferous area in Venezuela has become especially well known within the last few years because of a series of publications summarizing information on the history of discovery, geological setting, structural position of kimberlites, and their mineralogy, including the results of systematic studies of the diamonds and their inclusions (Channer and Cooper, 1997; Channer et al., 2001; Sobolev et al., 1998; Galimov et al., 1999; Kaminsky et al., 2000). An extensive drilling program was conducted on the kimberlites, and the availability of abundant fresh material from the drill core allowed the kimberlites to be dated at $710 \mathrm{Ma}$ (phlogopite $\mathrm{Rb} / \mathrm{Sr}$ ), and confirmed their similarity with typical kimberlites (Channer and Cooper, 1997; Channer et al., 2001). Kimberlites form in general eight sheets (sills), occupying a $10 \mathrm{~km}$ long by $5 \mathrm{~km}$ wide zone with thicknesses varying from 0.1 $3.7 \mathrm{~m}$, with an average of $1.2 \mathrm{~m}$ based on 235 drill hole intersections (Channer et al., 2001).

A detailed study of inclusion - bearing diamonds led to the very significant conclusion that the eclogitic (E) type of inclusion paragenesis reached $99 \%$, compared with the ultramafic (U) type (Sobolev et al., 1998). This result was further confirmed by $\mathrm{C}$ isotopic study of Guaniamo diamonds (Galimov et al., 1999). A subsequent study of Guaniamo diamonds and inclusions by Kaminsky et al. (2000) reached a similar conclusion, although a slightly lower (86\%) proportion of E-type diamonds was found. Further examination of inclusions from a new and larger sample set of Guaniamo diamonds allowed us to increase considerably the data base. This publication focuses mainly on the significance of polymineralic inclusion assemblages with regard to compositional variations in a dominantly eclogitic source region for Guaniamo diamonds.

\section{DIAMONDS}

More than 4500 diamond crystals from the Guaniamo kimberlite sheets, including diamond fragments, were examined in order to select from among them those containing mineral inclusions. As a result of careful visual examination of the available collection, 322 diamonds were selected for study of their mineral inclusions. Most of the examined collection (80\%) is represented by crystals between 1 and $2 \mathrm{~mm}$ in size, with an average weight for single crystals of about 10 $\mathrm{mg}$. $20 \%$ of the diamonds are of greater weight, reaching 0.4 carats. Microdiamonds $(<1 \mathrm{~mm})$ contain very rare inclusions. Diamond morphological characteristics are published elsewhere (Sobolev et al., 1998; Kaminsky et al., 2000) and inclusions data only are discussed below.

\section{ANALYTICAL METHODS}

Micro-Raman spectroscopy has been used for nondestructive inclusion identification as well as synchrotron single-crystal diffraction measurements of the inclusions volume compression. FTIR spectroscopy has been applied for the study of incorporation of hydrogen into the coesite and omphacite structure.

Mineral inclusions were released from diamonds both by crushing and burning as well as by polishing host diamonds until inclusions were exposed. Inclusion grains, as well as polished fragments of diamonds with exposed inclusions, were mounted on epoxy resin and polished for analysis. Major elements were analyzed with a CAMEBAX electron microprobe at Novosibirsk. The analyses were performed at $15 \mathrm{kV}$, with a $20 \mathrm{nA}$ beam current, and a $1-5 \mu \mathrm{m}$ spot size. Counting times varied from $20 \mathrm{~s}$ for major elements to $100 \mathrm{~s}$ for trace components.. All analyses EMP data were fully corrected by the Cameca PAP ( ZAF) software.

\section{MINERAL INCLUSIONS}

The majority of the inclusion-bearing diamonds contained more than one included mineral grain. Total number of inclusions from 322 diamonds was about 700 grains. This includes up to 5-10 grains of similar minerals (garnets or omphacites) in single diamond. About $40 \%$ of all examined crystals contained more 
than one inclusion phase. E-type pyroxene is a dominant phase followed by sulfides, garnet, coesite, rutile, sanidine, magnetite, and ilmenite. Phlogopite, corundum, kyanite, and moissanite are rare inclusions. Sulfide abundance was estimated only for diamonds containing an additional, different phase.

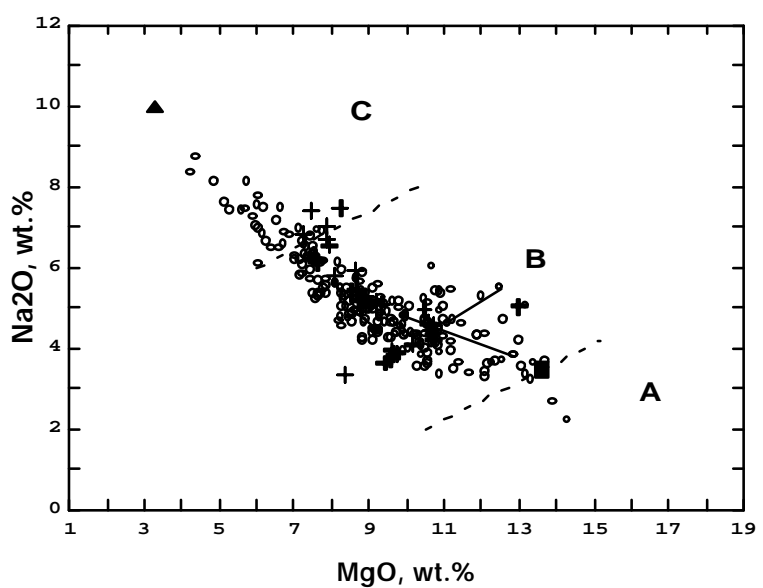

Figure 1: $\mathrm{MgO}$ (wt.\%) vs. $\mathrm{Na}_{2} \mathrm{O}$ (wt.\%) plot for omphacites from Guaniamo diamonds relative to the classification scheme of Taylor and Neal (1989). Open circle - pyroxenes from Guaniamo diamonds (this study), solid triangle - jadeitic pyroxene intergrown with kyanite, solid square - omphacite intergrown with enstatite (see Table 1), crosses - pyroxene data from Kaminsky et al., 2000.

Omphacite is considerably more common in Guaniamo E-type diamonds compared with garnet. The proportion of omphacite to garnet in the studied collection is about 65 to 35. The compositional range in terms of $\mathrm{MgO}$ and $\mathrm{Na}_{2} \mathrm{O}$ contents (Fig. 1) is extremely wide. $\mathrm{Na}_{2} \mathrm{O}$ contents vary from 2.26 to $10 \mathrm{wt} . \%$, which corresponds to $16-67$ mol.\% jadeite, with a total range of about 50 mol.\% jadeite. This is the widest range in omphacite compositions observed so far for an individual diamond deposit.

Very important link between U-type and E-type parageneses (Sobolev, 1977; Meyer, 1987) is confirmed by diamond sample Gm-97-32 (see Table 1) containing polymineralic inclusion of omphacite, enstatite and Etype garnet and representing websteritic paragenesis (Sobolev et al., 1999).

Garnets contain $\mathrm{Fe}, \mathrm{Mg}$ and $\mathrm{Ca}$ in varying proportions and lie within the typical range of compositions of Etype garnets included in diamonds worldwide (Meyer, 1987). Extreme compositional variations were observed for two isolated garnets inclusions within single diamond. These variations include variable $\mathrm{CaO} 2.91$ and 11.9 wt.\%; Mg\# 68.4 and 52 which practically covers whole compositional range for E-type garnets included in diamonds (Sobolev et al., 1999).

Table 1: Compositions of selected polymineralic inclusions from Guaniamo diamonds

\begin{tabular}{llllll} 
Sample & \multicolumn{2}{c}{$\mathrm{Gm}-97-32$} & \multicolumn{3}{c}{ Gm-97-12 } \\
& \multicolumn{3}{c}{ Intergrowth } & \multicolumn{2}{l}{ Intergrowth } \\
& $\mathrm{Ga}$ & $\mathrm{Opx}$ & $\mathrm{Cpx}$ & $\mathrm{Cpx}$ & $\mathrm{Ky}$ \\
$\mathrm{SiO}_{2}$ & 40.0 & 55.7 & 55.0 & 58.3 & 37.4 \\
$\mathrm{TiO}_{2}$ & 0.45 & 0.06 & 0.40 & 0.62 & 0.13 \\
$\mathrm{Al}_{2} \mathrm{O}_{3}$ & 21.8 & 0.51 & 4.71 & 19.2 & 60.0 \\
$\mathrm{Cr}_{2} \mathrm{O}_{3}$ & 0.02 & 0.01 & 0.06 & 0.07 & 0.07 \\
$\mathrm{FeO}$ & 21.0 & 15.7 & 7.37 & 2.89 & 0.35 \\
$\mathrm{MnO}$ & 0.82 & 0.13 & 0.08 & 0.03 & 0.00 \\
$\mathrm{MgO}$ & 9.84 & 27.6 & 13.6 & 3.30 & 0.10 \\
$\mathrm{CaO}$ & 6.63 & 0.48 & 15.1 & 4.97 & 0.00 \\
$\mathrm{Na} 2 \mathrm{O}$ & 0.27 & 0.19 & 3.47 & 10.0 & 0.00 \\
$\mathrm{~K}_{2} \mathrm{O}$ & $\mathrm{Nd}$ & 0.01 & 0.11 & 0.11 & 0.00 \\
$\mathrm{NiO}$ & $\mathrm{Nd}$ & nd & $\mathrm{Nd}$ & $\mathrm{Nd}$ & $\mathrm{Nd}$ \\
$\mathrm{Total}$ & 100.8 & 100.3 & 99.9 & 99.4 & 98.0 \\
$\mathrm{Mg} \#$ & 45.5 & 75.8 & 76.6 & 67.0 & 33.7
\end{tabular}

Sample K-024-203

\begin{tabular}{llll} 
& & \multicolumn{2}{l}{ Intergrowth } \\
$\mathrm{SiO}_{2}$ & 41.3 & Chr & Opx \\
$\mathrm{TiO}_{2}$ & nd & 0.15 & 58.4 \\
$\mathrm{Al}_{2} \mathrm{O}_{3}$ & nd & 8.50 & 0.01 \\
$\mathrm{Cr}_{2} \mathrm{O}_{3}$ & 0.04 & 62.0 & 0.45 \\
$\mathrm{FeO}$ & 7.17 & 13.9 & 4.15 \\
$\mathrm{MnO}$ & 0.10 & 0.22 & 0.11 \\
$\mathrm{MgO}$ & 51.1 & 13.6 & 36.4 \\
$\mathrm{CaO}$ & 0.01 & nd & 0.37 \\
$\mathrm{Na} 2$ & nd & nd & 0.01 \\
$\mathrm{~K}_{2} \mathrm{O}$ & nd & nd & 0.00 \\
$\mathrm{NiO}$ & 0.38 & 0.10 & $\mathrm{Nd}$ \\
$\mathrm{Total}$ & 100.1 & 98.5 & 100.5 \\
$\mathrm{Mg} \#$ & 92.7 & 60.0 & 94.0
\end{tabular}

Sulfides associated with E-type minerals were liberated from about 30 diamonds. They are pyrrhotites showing only traces of Ni significantly less than 1 wt.\% which confirms our previous observations (Sobolev et al., 1998; Yefimova et al., 1983).

Chromite-enstatite intergrowth (see Table 1) was documented among polymineralic inclusions. This diamond sample represents one of five diamonds from available collection containing U-type inclusions. Compositional features of touching chromite and 
enstatite and isolated olivine (Mg\# 92.7) indicate their equilibrium and similarity to harzburgitic paragenesis (Sobolev, 1997). Very important differences in compositions of two studied orthopyroxenes (see Table 1) should be noted. Orhtopyroxene coexisting with omphacite contains no $\mathrm{Cr}$, high $\mathrm{Fe}$ and significant $\mathrm{Na}$ which may be used as distinguishing features even for isolated orthopyroxene inclusion of similar composition.

\section{DISCUSSION}

The present study confirms previous conclusions on the exceptional significance of the E-type paragenesis for the majority of Guaniamo diamonds (Sobolev et al., 1998; Kaminsky et al, 2000). Careful examination of the available collection led to the discovery of a high proportion of diamonds containing more than one included phase and up to 40 diamonds containing touching inclusions. Among the touching inclusions, the omphacite-rutile intergrowths observed in 15 diamonds are of special importance. Omphacite in direct contact with (exsolved) rutile contains much less $\mathrm{TiO}_{2}$ (approximately $0.25 \mathrm{wt} \%$ ) than associated omphacite grains not in contact with rutile in the same diamond; these latter grains typically contain $0.5-0.7$ $\mathrm{wt} \% \mathrm{TiO}_{2}$. A variety of colorless minerals is present in approximately $25 \%$ of the diamonds with inclusions. Coesite along with retrograde quartz (sometimes in the same diamond) is typical of about $19 \%$ of all diamonds, followed by sanidine (4\%) and single samples with corundum and kyanite. Phlogopite was identified in two samples. One of them represents intergrowth with omphacite (Sobolev et al., 1998). Moissanite was also identified in two samples, in particular, with omphacite in one diamond.

The very wide measured variations in compositions of garnets and omphacites have fully confirmed our previous conclusion (Sobolev et al., 1998; 2000) on the broadly basaltic chemistry of the dominant eclogitic source region in which diamonds formed beneath the Guyana shield.

In previous work a broad range of equilibration temperatures $\left(1000^{\circ} \mathrm{C}-1300^{\circ} \mathrm{C}\right)$ for 33 garnet-omphacite pairs of inclusions was estimated, with an average of about $1200^{\circ} \mathrm{C}$ at a pressure of $55 \mathrm{kbar}$ (Sobolev et al., 1998). In this study a further 26 garnet-omphacite inclusion pairs were analyzed, with the results for all 59 pairs confirming the previous equilibration temperature estimates. The fossilized high pressures represented by coesite inclusion were identified and measured "in situ" using laser Raman and synchrotron X-ray microanalytical techniques (Sobolev et al., 2000).
Detailed study of the abundant polymineralic inclusions has confirmed that equilibrium conditions prevailed during formation of the bulk of the examined diamonds. However, a number of samples demonstrate a complex history of diamond growth. Significant differences in the compositions of some pyroxenes, both in terms of $\mathrm{Na}_{2} \mathrm{O}-\mathrm{MgO}$ content (see Fig. 1, points connected by solid lines) and in $\mathrm{K}_{2} \mathrm{O}$ content, possibly related to different diamond growth zones, testify to varying geochemical conditions in an E-type environment during diamond growth.

\section{CONCLUSIONS}

All known E-type parageneses of diamonds worldwide (e.g. Sobolev, 1977; Meyer, 1987) are represented as sets of polymineralic inclusions in diamonds from Guaniamo area Venezuela. The E-type vs U-type ratio is more than 98\%. These parageneses include: bimineralic eclogites, rutile eclogites, magnetiteilmenite eclogites, corundum eclogites, kyanite eclogites, coesite eclogites, coesite-sanidine eclogites. Bimineralic and coesite eclogites equilibrated at $1200^{\circ} \mathrm{C}$ on average at pressures about 55-60 kbars determined by direct measurement of the shift of a position of a coesite peak by nondestructive Raman spectroscopy supported by synchrotron single-crystal-diffraction measurements of coesite volume compression (Sobolev et al., 2000).

Significant hydrogen content about $900 \mathrm{H}$ ppm was determined for coesite "in situ" in diamond (KochMueller et al., 2003). Equilibration conditions as well as variability of E-type parageneses are close to those for Argyle diamonds (Sobolev, 1998).

\section{REFERENCES}

Channer, D.M.DeR., Cooper, R.E.C., 1997. The Guaniamo diamond region, Bolivar state, Venezuela: A new kimberlite province. Memorias del VIII Congreso Geologico Venezolano Society. Venezolana de Geologia 1. 143-146.

Channer, D.M.DeR., Egorov, A., Kaminsky, F., 2001. Geology and structure of the Guaniamo diamondiferous kimberlite sheets. South-west Venezuela. Revista Bras. Geocien. 31, 615-630.

Galimov, E.M., Sobolev, N.V., Yefimova, E.S., Shiryaev. A.A., 1999. Carbon isotopic composition of Venezuelan diamonds. Dokl. Akad. Nauk 364, 64-68 (in Russian).

Kaminsky, F.V., Zakharchenko, O.D., Griffin, W.L., Channer, D.M.DeR., Khachatryan-Blinova, G.K., 
2000. Diamond from the Guaniamo area, Venezuela. Canad. Mineral. 38, 1347-1370.

Koch-Mueller, M., Dera, P., Fei, Y., Reno, B.L., Sobolev, N.V., Hauri, E., Wysoczanski, R., 2003. OH in synthetic and natural coesite. American Mineralogist (in press).

Meyer, H.O.A., 1987. Inclusions in diamonds. In: Nixon. P.H. (Ed.). Mantle xenoliths. Chichester, England. John Wiley and Sons. pp. 501-522.

Sobolev, N.V., 1977. Deep-seated inclusions in kimberlites and the problem of the composition of the upper mantle. Washington D.C. American Geological Union.

Sobolev, N.V., Fursenko, B.A., Goryainov, S.V., Shu, J., Hemley, R.J., Mao, H.K., Boyd, F.R., 2000. Fossilized high pressure from the Earth's deep interior: the coesite-in-diamond barometer. Proc. Natl. Acad. Sci. USA 97, 11875-11879.

Sobolev, N.V., Sobolev, V.N., Snyder, G.A., Yefimova, E.S. Taylor, L.A., 1999. Significance of eclogitic and related parageneses of natural diamonds. Intern. Geol. Rewiew 41, 129-140.

Sobolev, N.V., Yefimova, E.S., 2000. Composition and petrogenesis of Ti-oxides associated with diamonds. Intern. Geol. Review 42, 758-767.

Sobolev, N.V., Yefimova, E.S., Channer, D.M.DeR., Anderson, P.F.N., Barron, K.M., 1998. Unusual upper mantle beneath Guaniamo. Guyana shield. Venezuela: evidence from diamond inclusions. Geology 26. 971974.

Taylor, L.A., Neal, C.R., 1989. Eclogites with oceanic crustal and mantle signatures from the Bellsbank kimberlite. South Africa. Part 1: Mineralogy, petrography and whole-rock chemistry. Journ. Geol. 97, 551-567.

Yefimova, E.S., Sobolev, N.V., Pospelova, L.N., 1983. Sulfide inclusions in diamonds and specific features of their paragenesis. Zapiski Vsesoyuznogo Mineralogicheskogo Obschestva 112, 300-310 (in Russian).

Contact: N.V.Sobolev, Institute Mineralogy and Petrography, Novosibirsk, 630090, Koptyug ave., 3, Russia. E-mail:

sobolev@uiggm.nsc.ru 